\title{
Impact of short term HAART initiated during the acute or chronic stage on SIV infection of the male genital tract
}

\author{
Marina Moreau", Anna Le Tortorec ${ }^{1}$, Hélène Denis ${ }^{1}$, Claire Deleage ${ }^{1}$, Anne-Pascale Satie ${ }^{1}$, Olivier Bourry ${ }^{1}$, \\ Pierre Roques ${ }^{2}$, Bernard Jégou' ${ }^{1}$, Roger Le Grand ${ }^{2}$, Nathalie Dejucq-Rainsford ${ }^{1}$
}

From $16^{\text {th }}$ International Symposium on HIV and Emerging Infectious Diseases

Marseille, France. 24-26 March 2010

\section{Background}

We previously evidenced the infection of human and macaque semen-producing organs by HIV-1 and SIV (Le Tortorec et al, Plos One, 2008; Le Tortorec et al, Retrovirology, 2008; Roulet et al, Am J Pathol, 2006). The male genital tract (MGT) is suspected to constitute a viral reservoir since persistent HIV shedding is found in the semen of a subset of HIV infected individuals under effective HAART (undetectable viremia). Using a macaque model, we investigated the impact of short term HAART initiated during the acute or chronic stages, on SIV infection of the MGT.

\section{Methods}

Adult male Cynomolgus macaques were treated with AZT/3TC/IDV for 2-4 weeks at $4 \mathrm{~h}$ and 21 weeks postintravenous inoculation (p.i.) of $\mathrm{SIV}_{\mathrm{MAC251}}$. The presence of SIV in the testis, epididymis, prostate and seminal vesicles was analyzed at the end of the treatment period by nested PCR for SIV gag DNA and in situ hybridization for SIV gag RNA.

\section{Results}

HAART initiated $4 \mathrm{~h}$ post-infection prevents the peak of plasma viral load (PVL) and leads to a significant decrease of the virus dissemination in MGT tissues. In macaques treated during the chronic stage, the frequency of viral DNA detection in MGT tissues is on average similar to that of placebo animals, with the exception of 2 animals with an undetectable PVL, in whom a decrease of viral DNA detection is observed in all MGT organs, but to a lesser extent in the testis. In all animals including those with undetectable viremia, SIV RNA+ cells are still detected in the MGT organs following HAART.

\section{Discussion}

Short term HAART initiated post exposure dramatically reduces SIV dissemination in the MGT. Although efficient short term HAART initiated during the chronic stage decreases the level of infection of the MGT, SIV RNA+ cells can still be detected within the tissues. Whether prolonged HAART can eradicate SIV from the MGT will next be investigated.

\section{Author details}

${ }^{1}$ Inserm U625 GERHM, Rennes, France. ${ }^{2}$ Service d'immuno-virologie, CEA,

Fontenay-aux-roses, France.

Published: 11 May 2010

doi:10.1186/1742-4690-7-S1-P11

Cite this article as: Moreau et al.: Impact of short term HAART initiated during the acute or chronic stage on SIV infection of the male genital tract. Retrovirology 2010 7(Suppl 1):P11.

* Correspondence: marina.moreau@univ-rennes1.fr

${ }^{1}$ Inserm U625 GERHM, Rennes, France 